\title{
Performing Heritage: the use of live 'actors' in heritage presentations
}

\section{JACQUELINE TIVERS}

Department of Planning, Anglia Polytechnic University, Bishop Hall Lane, Chelmsford, CM1 1SQ, UK

This paper investigates the phenomenon of 'living history' presentations of heritage, using live 'actors' to portray historical characters. Its aim is to discuss these presentations in the context of what may be understood as 'heritage', and of the nature of 'performance'. Four case studies of heritage sites, each important as a tourist attraction, have been selected for detailed study, together with a number of other examples of heritage performance. It is clear from the empirical work that different performance strategies are employed within the heritage industry and by individual 'actors'. Most of the performers take part as a leisure activity, and many do not consider themselves to be 'performing' at all. The greatest concern of participants lies in the degree of authenticity of the performance. Through 'living history', the 'actors' are drawn into an experience of heritage which has real meaning for them, and which may contribute both to a sense of identity and to an enhanced understanding of 
society, past and present. The popularity of such presentations with visitors also indicates that similar benefits are perceived by the 'audience'.

\section{Introduction}

'Living history’ presentations have been described as '...sites where live actors participate in the telling of a story of the past'(Mills and Tivers, 2000, 1). This paper selects a number of case studies and examples for research and discussion, to elucidate the different ways in which such presentations may be viewed as 'performances'. In order to set the case studies in context, the paper first approaches the two concepts of 'heritage' and 'performance' and then uses these concepts in discussing the nature of the different 'living history' presentations.

\section{Heritage}

Crang $(1994,341)$ points out that ' ...the past is not an immutable or independent object. Rather it is endlessly revised from our present positions. History cannot be known save from the always transitional present ... there are always multiple constructions of the past'. History, in other words, is never an objective recall of the past but always a selective interpretation, based on the way in which we view ourselves in the present. 'It is not just any old happenstance history that is allowed to unfold. It is 'specific pasts' and 'rewritten pasts' that are permitted to unfurl' (Hollinshead, 1997, 179). Schouten $(1995,24)$ points out that 
'History has always been written by the winners and not by the losers, and winning in itself does not provide historical truth’.

'Heritage', too, is not unproblematic. Definitions vary widely, from the literal meaning of something that is inherited, through '...the provision of goods and services that come from or relate to a past in some way, however vaguely ... [to] a feeling of generalized quality, continuity or simply familiarity and wellbeing' (Graham et al., 2000, 1-2). However we define 'heritage' it is clearly not the same thing as 'history', although, like history, 'Heritage is not an object seen as existing independently of how it is experienced' (Crang, 1994, 342). Schouten $(1995,21)$ says that 'Heritage is history processed through mythology, ideology, nationalism, local pride, romantic ideas or just plain marketing, into a commodity’. It implies the commodification of history. Heritage is the use of the past for contemporary purposes; it can only be logically defined (whatever the definition chosen) in terms of a market (Ashworth and Tunbridge, 1990), whether that market be economic in character or socio-political in function.

The term, 'heritage', may include such diverse elements as mythical sites and characters (e.g. Robin Hood in Sherwood Forest - see Rojek, 1994, 146), reconstructions of real places (e.g. the city of Ephesus in Turkey), new sites where there was nothing before (e.g. Wigan Pier - see Hewison, 1987), locations where significant features no longer exist (e.g. the Berlin Wall), museum collections, Medieval 'Fayres’, community culture, vernacular building styles, and the ways of life of people in the past. Many of these elements, or approaches, have encouraged the development of 'living history' presentations, where live actors occupy either specific or generalised historical roles. These 
presentations (or 'performances') will be discussed later in the paper. However, in order to set these in context, consideration will first be given to the nature of 'performance' and the ways in which it is understood at the present time.

\section{Performance}

The notion of 'performance' is very broad, whether one considers the literature of theatre studies or that of anthropology. "The term "performance" has become extremely popular in recent years in a wide range of activities in the arts, in literature, and in the social sciences. As its popularity and usage has grown, so has a complex body of writing about performance, attempting to analyze and understand just what sort of human activity it is’ (Carlson, 1996, 1). Milling and Ley $(2000,174)$ note, for example, that 'The developing discourse of theorized performance might include semiotics, theatre anthropology and interculturalism, and feminist or sexual politics or identity politics’. Diamond $(2000,69)$ states that 'To study performance is not to focus on completed forms, but to become aware of performance as itself a contested space, where meanings and desires are generated, occluded, and of course multiply interpreted'.

Traditionally, 'performance' could be described as a '...loose cluster of theatrical practices, relations, and traditions’' (Parker and Sedgwick, 1995, 1). Counsell $(1996,3)$ describes the way in which, within theatre, narrative is '...enacted live, by performers who occupy the same physical time/space as the audience. Each performer will use their everyday expressive resources - voice, gesture, movement and so on - to construct a fictional participant in the 
narrative, a character, which will function as the notional author of the actor's words and actions'. He goes on to say that 'The whole performance will take place in an agreed venue for representation, in which the spaces and functions of spectators and actors are strictly separated' (Counsell, 1996, 3), although he does accept that twentieth century theatre has challenged these underlying assumptions. According to Abercrombie and Longhurst (1998, 42) '...performers acquire a mystique which separates them from the ordinary lives of the audience. They are a separate order of beings inhabiting an extramundane world'.

Within the literature of theatre studies it is generally accepted that for a 'performance' to take place there must be an audience. Despite the fact that the term is '....an essentially contested concept...Performance is always performance for someone, some audience that recognizes and validates is as performance' (Carlson, 1996, 5-6). Goodman (1996, 30) says that 'The dynamic of the theatre, as opposed to the performances of everyday life, is unique in terms of the presence of an immediate and critical body of spectators. The theatre space encourages immediate reactions from the audience and permits a level of criticism which is not deemed appropriate in most forms of social interaction'. Thus, there is no necessity for the 'audience' to be seen as passive recipients of a performance (indeed, one only has to look at the Elizabethan theatre to see that spectator passivity is by no means a traditional characteristic). Abercrombie and Longhurst (1998, 40), quoting Turner (1982), point out that ‘...performance involves a relationship between performer and audience in which a liminal space, however slight, is opened up. The performer-audience interaction occurs within, or represents, critical areas in which a society is self- 
reflexive; it provides a kind of window, 'a limited area of transparency', through which an examination of socially and culturally sensitive issues is possible'. Campbell $(1996,2)$ notes that 'The active role of an audience, linked to debates about the gendered gaze and representation of the acting body, is ... a current preoccupation of feminist theatre'. Similarly, the importance of a segregated 'performance space' as a characteristic of theatrical performance is the subject of critical appraisal; Kershaw (1999, 19), for example, views 'performance beyond theatre' as the radical force of performance, in contrast to the discipline exerted by the theatre.

Many postmodern plays take as their theme an exploration of the nature of performance itself: ‘... 'performance’ for all these works marks the point at which theatre opens out beyond itself, marks theatre as the very movement of opening beyond oneself. As such, they involve active and transforming reflection upon the nature of freedom, identity and action’ (Connor, 1996, 123). As theatre questions 'What does it mean to perform?' (Connor, 1996, 107) and moves outwards, beyond the stage, into the streets, and away from the traditional barriers between 'performers' and 'audience', so at the same time more and more of life is viewed as 'performative’ (a concept which derives originally from literature and which implies the active performance of words as in christening a ship, or making marriage vows, for example).

'Performance ... though it frequently makes reference to theatricality as the most fecund metaphor for the social dimensions of cultural production, embraces a much wider range of human behaviors. Such behaviors may include what Michel de Certeau calls "the practice of everyday life", in which the role of spectator expands into that of participant. De Certeau's "practice” has itself 
enlarged into an open-ended category marked "performative”' (Roach, 1995, 46). A similar point is made by Kershaw $(1996,133)$ : ‘...the mediatisation of developed societies disperses the theatrical by inserting performance into everyday life - every time we switch into the media we are immediately confronted by a performative world of representational styles...'. Kershaw attributes the growing interest in 'performance' by scholars in a wide variety of fields to the growing importance of this 'performative society', a society which relies on various types of performance for the maintenance of political processes and social structures; he cites economic 'performance' as one example of this (Kershaw, 1999, 13). It is widely acknowledged that, as Williams (2000) asserts, we live in a ‘dramatized society’. Abercrombie and Longhurst (1998, 72-73) state that: 'So deeply infused into everyday life is performance that we are unaware of it in ourselves or in others. Life is a constant performance; we are audience and performer at the same time ...'. Not that this is a new concept. It seems impossible here to avoid quoting Shakespeare: 'All the world's a stage and all the men and women merely players'.

Milling and Ley $(1996,175)$ attribute the extension of the study of performance into areas like ritual, play and social behaviour to the theatre theorist and anthropologist, Richard Schechner, with whom we associate the term 'restored behaviour' as a descriptor of 'performance'. 'Restored behaviour' may be described as 'that which can be repeated, rehearsed, and above all recreated ... [involving] bodily knowledge, habit, custom' (Parker and Sedgwick, 1995, 46-47). Pretending to be someone else (as in the theatre) is, of course, an example of 'restored behaviour', but instances are found within a 
much wider context of anthropology, sociology and psychology. As Carlson (1996, 34) points out, in some senses all behaviour is 'performed' and all relationships may be viewed in terms of 'roles'. 'Performance' in this sense could be considered to be 'all activity carried out with a consciousness of itself' (Carlson, 1996, 4), or 'the conscious occupation of a role' (Day, 2001), and does not therefore, of necessity, require an audience outside of the self. So, for example, Butler (1990) describes gender as ‘performative’. Diamond (2000, 67) states that: 'Performances [may be seen] ... as cultural practices that conservatively reinscribe or passionately reinvent the ideas, symbols, and gestures that shape social life'. In an unusual twist, Fusco (2000) gives an interesting example of an actor performing the role of a savage in a cage, where a substantial proportion of the public believed that the fictional identity was real, because of the performative quality of race and 'otherness'.

To summarise a wide and varied body of literature, Connor (1996, 107108) says that to 'perform' '...means to do something, to execute or carry out an action ... 'to perform' just means to act in certain ways'. But it also means '...to enact - to play out or impersonate'. He says that '... one of the salient features of postmodern performance ... is its capacity to explore the compounding of action and enaction, immediacy and repetition, event and work'. Diamond $(2000,66)$ goes further: ‘...performance is always a doing and a thing done. On the one hand, performance describes certain embodied acts, in specific sites, witnessed by others (and/or the watching self). On the other hand, it is the thing done, the completed event framed in time and space and remembered, misremembered, interpreted, and passionately revisited across a pre-existing 
discursive field ... Every performance ... embeds features of previous performances: gender conventions, racial histories, aesthetic traditions ...'.

Issues raised within this section and the previous one, which have explored the theoretical concepts of 'heritage' and 'performance' will be discussed in the context of empirical case studies of 'living history' or 'heritage performance' in the succeeding sections of this paper.

\section{'Living history'}

Robertshaw (from the 'History Re-Enactment Workshop') takes a very specific and narrow view of 'living history', including only first person interpretation (where the 'actor' takes a specific historical role and speaks 'in character'), and excluding drama, Theatre in Education, guiding, craft demonstration, third person interpretation, and battle re-enactments. He justifies this by stating that 'Only first person interpretation calls for a mix of historical knowledge, educational objectives and performance skills'(Robertshaw, 1997). A broader definition is usually applied, and will be employed in this paper. 'Living history’ will here be considered to include all instances where live 'actors' participate in the telling of a story of the past.

The presentation of 'living history' goes back to just over one hundred years ago when Artur Hazelius, the founder of Skansen, the pioneering Museum of Scandinavian Folklore in Stockholm, introduced musicians and crafts people to breathe life into what he described as a "dry shell of the past" (Robertshaw, 1997, 1). The idea took hold in the United States and Canada in the middle years of the twentieth century, but its introduction into heritage presentation in 
the UK and other European and Western countries has been much more recent. Today the internet abounds with web pages devoted to historical re-enactment societies based in the UK, the US, Canada and Australia (Anglo-Saxon, Viking, Norman, Medieval, $16^{\text {th }}$ and $17^{\text {th }}$ century, Victorian, Great War, Second World War, etc.) and heritage sites with 'living history’ presentations (e.g. Living History Farms in Iowa, Cromarty Courthouse in Scotland). There are newsletters, discussion groups, lists of resources, events diaries, and exhortations to join and/or visit. In addition, several academic papers have been published which explore specific examples of ‘living history’ presentations (e.g. Halewood and Hannam, 2001, concerned with Viking heritage, and Taylor, 2001, looking at Maori heritage 'performances'). In the following sections, four site case studies, and some additional examples from a wider field of investigation, will be discussed in order to exemplify the previous discussion on heritage as 'living history’ and the nature of 'performance'.

\section{Case studies of heritage performance}

During 2000-2001 the author visited four case study sites, as detailed below. At each site, 'heritage performers' were observed in context, the author mingling with other tourists, before they were interviewed, singly and in small groups. Initially, these interviews took place with the 'performers' in character. At Llancaiach Fawr the respondents would not respond to questioning about their 'performance', but insisted on remaining in character throughout. An interview was subsequently held with the Manager of the house, at which questions were raised about heritage portrayal, the recruitment of people to play the parts of 
historical characters, historical research and the educational motivations of the project. At the other three sites, 'actors' were found who, as well as answering questions in character, also agreed to discuss their motivations for taking part in the historical re-enactments, their attitudes towards the importance of authenticity, their relationship with visitors/audience, and their own personal backgrounds. The following case study summaries describe the four sites and discuss the findings of the many interviews undertaken.

\section{Llancaiach Fawr}

At Llancaiach Fawr the visitor is presented with the social world of a seventeenth century gentry household from the perspective of (specific, named) servants, female and male, who discuss, amongst other issues, the class-based and gendered nature of domestic life. The setting is South Wales in 1645, during the Civil War. The total 'cast' comprises a large number of volunteers; local people who take specific roles at the house on a rota basis. All the individual roles share the same overall story, so that it is unimportant which particular characters are met by visitors. The 'actors' are there as 'performers', interacting directly with individual, or groups of, visitors, who are perceived as the 'audience'. They are as dedicated to the educational value of the 'living history' experience as are the owners of the house. Although there is an admission charge, the concern is for historical accuracy (in dress, speech, domestic activities, etc.) and not for commercial advantage.

Llancaiach Fawr is exemplary in its efforts to portray as accurately as possible the true situation of seventeenth century servants. The museum has won a number of awards including one in 1995 from the Society for the 
Interpretation of Britain’s Heritage - an ‘Award for First Person Interpretation in recognition of excellent interpretative practice contributing to greater awareness and understanding of Britain’s heritage' (quoted from the plaque in the entrance hall). Unfortunately, such explicit interpretation is by no means common. Holcomb $(1998,41)$ notes (with some irony) that '...the growth industry of historical re-enactments - heritage in action - has more than its share of chaps dressed in period military costumes and playing with weird weapons, though there are, of course, serving wenches and dancing girls at medieval festivals'. Issues of class, and indeed race, are now being addressed at heritage sites, where once such important elements were routinely excluded (Mills, 1997, 112), but ' ...the gendered perspectives of such sites have gone unnoticed, even though merely incorporating women into the narrative often ensconces them within a family space defined in traditional male fashion. The male/public, female/private dichotomies are taken for granted. Whether such dichotomies are appropriate for any past period, expectations of an interior, domestic, female world can blind present day interpreters in terms of what they themselves see, and thus what they provide' (Mills and Tivers, 2000, 4-5). It is rare for stereotyped and idealised, historical gender roles to be problematised (as at Llancaiath Fawr), so that visitors' perceptions and assumptions can be challenged - and yet, this should be one of the strengths of 'living history' presentations.

\section{Kentwell Hall}

'A truly unique experience - the $16^{\text {th }}$ century comes to life at Kentwell'. In the early summer of 2001, it was May Day 1579. Kentwell is a moated Tudor 
mansion in Suffolk, East Anglia, open to the (paying) public, and at certain times in the year home to a large number of Tudor re-enactors who gather there from all over the country. The 'performance' of Tudor heritage was the idea of the owner of Kentwell Hall, who was inspired by 'living history' presentations in North America. He is directly involved with the choice of the specific date to be re-created (it changes each year), the number of people to be involved (from 20 to 250, depending on the specific re-creation) and the types of activities to be illustrated. He pays the travelling expenses of the 'actors' and supplies them with meals while they are on site. He even takes part himself, in costume, when time and circumstances permit.

The introductory leaflet to the house describes a 'historical re-creation' as 'Re-Creating, as authentically as possible, everyday life at the date chosen. Those taking part dress, behave, act and talk as of the period chosen and at no time do they ever come out of role. Thus, for visitors, it is as if they were meeting figures out of the past'. However, the 're-creations' are much more than a way of attracting visitors, or even of providing an educational experience (as at Llancaiath Fawr); at Kentwell, there is a deep commitment to the idea of re-enactment in itself. The 'Tudors' who are part of the company return again and again - some have been coming for many years. It is a very important part of their social life. They say that they are much more interested in 'being Tudors' than in meeting visitors; sometimes the visitors may prove a big distraction to the way of life they are trying to participate in. One woman said that she enjoyed the 'simple life' of spinning and weaving, which she would not find time to do at home in her normal life. The 'Tudors' do not consider themselves to be 'actors', although it is possibly a mistake to think that they are 
not 'performing' just because they insist they are not. They clearly 'perform' to each other, and to themselves, regardless of the presence or absence of visitors. However, if 'performance' is the conscious occupation of a role, it is interesting to consider how conscious are these re-enactors of taking a role. They seem to work very hard to make their role unconscious, and in that sense might perhaps not be described as 'performers' in the context of the definition adopted in this paper. They become 'Tudors' when they enter Kentwell, and remain in character until they leave. Consequently, they are extremely good at first person interpretation. As at Llancaiath Fawr, issues of gender and class are dealt with openly and thoughtfully; for example, the existence of a woman archer is explained in context. The issue of disability is also faced directly; an old man, formerly the chief baker but now disabled from a stroke, is pulled around in a cart (as he would have been in Tudor times). It seems reasonable to suggest that it is the first person interpreters who are more ready and able to deal with these sorts of issues than are other types of heritage 'performers', since they have had to think through the lives of specific characters in detail (see also, Turner, 1982, 94).

\section{The Zuiderzeemuseum, Enkhuizen}

This Dutch open air and indoor museum on the shores of what used to be the Zuiderzee is a major tourist attraction, being located some $30 \mathrm{~km}$ from Amsterdam. In 2001 it put a special emphasis on 'Image and Reality', looking at how a museum can present 'reality' and concluding that it is an 'image' which is being presented, a reconstruction of history rather than history itself. The outdoor museum comprises houses and other buildings, representing the 
way of life before the enclosure of the Ijsselmeer in 1932. There are some costumed people in one part of the site - for example, a woman doing washing, another woman sitting in a cottage, a (male) commercial bank manager, a sailor in an old boat. The woman in the cottage discussed (in English, where visitors were English-speaking) the harshness of life in the 1930s, compared to the present, both in general terms and also specifically for women. The woman in the chemist's shop, measuring powders into phials, was costumed in character, but other shops, selling postcards and souvenirs, contained people in modern dress (not attempting to hide the commercial aspect of the site). According to one 'actor', only two families actually live on site; the others 'live' in their museum cottages during the day, but go home at night. The 'actors' are clearly employees of the museum who view themselves as 'performers', being present for the sake of the visitors (the 'audience'). They do not, however, pursue first person interpretation, possibly because so many visitors would be unable to understand Dutch. Instead, they are third person interpreters, comparing the way of life in the period represented with that pertaining today, and they fulfil a very real educational function by dressing and behaving in a spirit of historical accuracy.

\section{Warwick Castle}

Owned by the Tussaud's Group, Warwick Castle, in the English Midlands, is one of the most visited heritage sites in the UK. It has invested in a type of 'living history' for many years, although the figures in the 'Warwick the Kingmaker' and the 'Royal Wedding Party' exhibits are waxworks rather than live actors. However, there are some guides in costume (who do not act as 
'performers') within these two exhibitions; historians employed as third person interpreters. Considerable emphasis is put on the accuracy of the historical representation - of costume, artefacts, etc. - and on the education of visitors. In addition, in 2001, the Castle hosted a special 'Mediaeval Festival' during the summer months. The publicity leaflet invited the visitor to 'Join us this summer and experience the sights, sounds and smells of a mediaeval village. You can see brave knights in foot combat, the daily life of craftsmen and meet a host of Castle characters including the Warwick bowman and our very own Jester and the Ratcatcher. The excitement increases at the weekends with a spectacular programme of special events including Jousting ...'

The re-enactors were members of a local 'medieval society' (from Birmingham), employed as a group by the Castle management. They did not receive a salary as such, but payment covered expenses (travel, food, etc.). A group of 'medieval' men and women said that they attended the Castle every weekend in the summer, but noted that some of their number were present throughout the whole period. They described themselves as 'ordinary people' with an interest in the medieval period, not as 'actors'. Their participation was a 'hobby' (and in this they were very similar to the 'Tudors' at Kentwell). One woman said that she had been 'dragged into it' by her boyfriend, who had been a member for ten years. One of the men said that they did a lot of research on the period; he was keen to display his historical knowledge. They made their own, and their children's, clothes (there were many families within the group as also at Kentwell). As a group they agreed that the main motive of the management was commercial; having the re-enactors on site made visits more interesting and hence increased business. However, they themselves were not 
concerned with this aspect. A few, key characters (for example, the Red Knight) did first person interpretation (of a sort!), but the general opinion was that it would be very difficult to do this properly because no one really knew how people spoke at that time. They were therefore content in general to do third person interpretation and concentrate on the educational value of their reenactment.

They were clearly occupying a chosen and conscious role, and to that extent should probably be described as 'performers'. There was some public 'performing' (for example, jousting, music playing, walking on stilts) at set times during the day, but when away from these activities they did not appear as medieval 'performers', but rather as twenty-first century people dressed up in medieval clothes, doing basket making or some other craft of interest to the visitors. By their clothing they were very much 'part of the scene', but there was no real attempt to 'act the part'. Even the set 'performances' were more like side-shows than a representation of what might have taken place in medieval times, and there was little attempt to get into character. In this respect they were very different from the ‘Tudor' group at Kentwell Hall.

\section{Other examples of the use of 'living history' in presenting heritage}

In addition to visiting the four case study sites discussed above, and conducting observations and interviews at these sites, the author also undertook visits and discussions relating to the theme of 'living history' at a number of other sites. Some examples of these are outlined in this section. 
In August 2000, Cranleigh (a village in Surrey) put on a pageant to celebrate the Millennium. Probably, it was one of hundreds throughout the UK. The pageant was 'community theatre', performed by local people for local people. The standard of writing (and, in some cases, acting) was not particularly high; nevertheless, it was a real attempt to 'perform heritage', with actors occupying specific roles and a spectating audience, seated in a purposebuilt oudoor 'theatre'. This was not just any-old history that was presented, but the history of this particular place, with scenes depicting the local area at different times when national concerns impinged on its existence. Pride was shown in local heritage. People who perhaps would never have gone to a museum or read a history book took pleasure in learning about their own area in the past. Of course, the viewpoint was biased, as any look backwards is bound to be. Spectacular events (e.g. the Battle of Ockley) took precedence over everyday life, and the roles of men and women, commoners and gentry went unquestioned. Great efforts were, however, made (within the limits of time and finance) to present 'authentic' costumes and properties.

In a similar context it is possible to view Shakespeare's history plays as a way of 'performing heritage', using live actors (either professional or amateur) to tell the story of the past to an audience. Of course, the plays are not necessarily historically accurate (for example, Shakespeare's interpretation of Richard III), although it is true to say that his interpretations have been very influential in forming popular understandings of historical events and people. The essence of 'heritage' is the use of the past by the present, and that is very clearly seen in Shakespeare's works. It was crucially important to the Tudor dynasty (within which context Shakespeare was writing) to discredit their 
predecessors - hence the vilification of Richard III, for example. History, as noted earlier, has always been written by the victors, and Shakespeare's view of the past, performed on stage, is doubtless no more biased than many other 'histories’ (for example, the view of colonial American settlers as seen by modern American 'living history’ folk museums - see Mills, 1996).

Individual actors may sometimes be employed to 'perform' in character for a specific, commercial purpose as well as to entertain the 'audience'. For example, at the Wimbledon Tennis tournament in the summer of 2001, a woman dressed as a tennis champion of 100 years before was employed to encourage people waiting in the queue for tickets to visit the tennis museum on the site. She did first person interpretation and was a good actor, maintaining character throughout. The 'pirates' and other characters who entertain the queues of excursionists at theme parks might also be considered in this regard. Just because they have no very obvious educational function, and indeed are there for purely commercial reasons, it does not mean that they are any the less 'heritage performers', and the attention to historical detail is often very considerable.

Possibly best known amongst the general public are the many historical re-enactment societies which recreate battles from different periods. Some of these groups have been in existence for decades and their ritual engagements in Civil War, Napoleonic, or other battles are attended by large crowds of tourists and local on-lookers. The motivations of the participants are clearly very varied (and not all bellicose!), although an interest in a specific historical period, and involvement in a 'movement', are fairly prominent. One 'Viking' warrior (a relative of the author's) graduated from the 'reality' of the Territorial Army to 
the fantasy world of re-enactment on becoming a father; his wife also now takes part and their marriage was celebrated in full historical costume (a common feature also among the Tudor re-enactors at Kentwell Hall). As noted earlier (Holcomb, 1998), there is rather less concern within these groups for the questioning of social issues (for example, those concerning gender) than at the case study sites referred to earlier. Membership of a battle re-enactment group, however, takes up a substantial amount of an individual's leisure time, and indicates a strong degree of commitment, in the same way as does participation in other 'historical' groups, such as the Tudor and medieval life groups already referred to.

\section{Conclusions}

This paper has sought to enquire into the nature of 'performance' and the ways in which performance strategies are employed within the heritage industry. The case studies investigated, and other wider examples cited, show that heritage is 'performed' in different ways by different groups of, or individual, 'actors', many of whom would not consider themselves to be 'performing' at all, in a theatrical sense.

The concept of 'leisure' arises importantly from this study, having relevance for people on both sides of the 'performance divide'. All the case studies specified in this paper are tourist sites - places which, to a greater or lesser extent, depend on paying visitors to support their activities; visitors who choose to support such activities in their leisure time. In addition, while some professional actors are employed to take part in heritage performances, most of 
the 'performers' at these, and other, sites undertake 'living history' presentations as leisure activities which they choose to participate in (rather than, or as well as, belonging to a tennis club or a debating society or a darts team, for example). Many are seeking a 'simple life', possibly as a reaction to the pressures of twenty-first century living. The specific motivations of the 'performers', and the ways in which these relate to our understanding of 'performance' as a concept, is one of the most interesting aspects to emerge from the present study.

'Living history' (first person interpretation, as traditionally viewed) is normally considered to have, or even require, a strong educational element (see, for example, Robertshaw, 1997; Rumble, 1989), as well as good history credentials and an understanding of 'performance' skills. However, if the motivations of actual participants are examined, and if a wider variety of historical re-enactments is considered, it is clear to see that those involved in 'performing' may have no interest whatsoever in education, or indeed in an 'audience' of any sort outside of their own group - and in general have no interest in 'selling' heritage to anyone. To this extent, 'living history' stands in some respects to one side of the general commodification of history which creates heritage, although it may well be used to commercial advantage by tourism managers.

The one element which most strongly binds together the participants in 'living history’ is historical scholarship, research and a desire for 'authenticity’. The latter is considered an idealistic, rather than a realistic, aim by some writers. Uzzell $(1989,44)$, for example, says, '...the idea that we can somehow re-create the past must be challenged ... Freeze-framing our heritage ignores the 
psychological reality that neither those who provide interpretations of the past nor those who receive these interpretations can avoid loading them with their own twentieth-century perspectives. We cannot re-create the past or provide a 'truly authentic atmosphere', since visitors' perceptions of the past will always be influenced by their present-day attitudes and values’. Rumble $(1989,29)$ asks, ‘We can’t kill people on the battlefields; we can’t have dysentery and disease in medieval re-enactments. Do we debase people's understanding of the past because such events can’t be fully reproduced?'

It is almost impossible to answer such a question to any degree of satisfaction, and it is not the objective of the author, at this point, to enter into an academic debate about 'authenticity' and tourism. In this paper the main emphasis has been placed on the understanding and motivation of the 'performers', rather than the 'audience' (interest by the 'audience' being implied by the choice to visit the sites). The re-enactors, themselves, appear totally committed to their aim of 'authenticity', while at the same time recognising their own limitations. There is so much which is simply not known about the language and culture of past times, and hence re-enactment can only ever be partial. (First person interpretation is therefore rejected by many as an impossible ideal, or, worse, as a potential source of historical inaccuracy.) The benefit of 'performed heritage' does not lie so much in the totally accurate representation of the past as in the ability to question the past, to get inside the skin of women, and servants, and people of colour from a previous era, and so understand better the problems of gender, class and race in modern society. People can easily be misinformed by some heritage interpretations, or not encouraged to challenge ill-formed assumptions: ‘... the cynic could see 
evidence in the heritage product to argue that, far from being educative, it has had the effect of buttressing already deeply embedded perceptions’ (Fowler, 1989, 63). 'Living history’ presentations have a responsibility in this regard, but this does not relate so much to ‘authenticity' (in the strictly historical and academic sense) as to the encouragement of understanding of the past in the context of the present.

'Performance' is part of the way in which the world is viewed in postmodern times; it is intrinsic in society today. We live in a dramatized, or 'performative', society, where learning through experience is given more credence than learning through cognition. In the presentation of 'living history’ people are drawn into an experience of heritage which may have meaning for them, whether they are participants or 'audience', and which may contribute to a sense of identity and a better understanding of society, both past and present.

\section{References}

Abercrombie, N. and Longhurst, B. (1998) Audiences: A Sociological Theory of Performance and Imagination, Sage, London.

Ashworth, G.J. and Tunbridge, J.E. (1990) The Tourist-Historic City, Belhaven, London.

Butler, J. (1990) Gender Trouble: Feminism and the Subversion of Identity, Routledge, New York.

Campbell, P. (ed.) (1996) Analysing Performance: A Critical Reader, Manchester University Press, Manchester. 
Carlson, M. (1996) Performance: A Critical Introduction, Routledge, London.

Connor, S. (1996) Postmodern performance, in Campbell op. cit., pp. 107-124.

Counsell, C. (1996) Signs of Performance: An Introduction to TwentiethCentury Theatre, Routledge, London.

Crang, M. (1994) On the heritage trail: maps of and journeys to olde Englande. Environment and Planning D: Society and Space 12, 341-355.

Day, M.A. (2001) Personal communication.

Diamond, E. (2000) Performance and Cultural Politics, in The Routledge Reader

in Politics and Performance (edited by L. Goodman and J. De Gay), Routledge, London, pp. 66-69.

Fowler, P. (1989) Heritage: A Post-Modernist Perspective, in Heritage Interpretation: Vol.1: The Natural and Built Environment (edited by D. Uzzell), Belhaven, London, pp. 57-63.

Fusco, C. (2000) The Other History of Intercultural Performance, in Goodman and De Gay op. cit., pp. 130-135.

Goodman, L. (1996) Feminisms and theatres: canon fodder and cultural change, in Campbell op. cit., pp. 19-42.

Graham, B., Ashworth, G.J. and Tunbridge, J.E. (2000) A Geography of Heritage: Power, Culture and Economy, Arnold, London.

Halewood, C. and Hannam, K. (2001) Viking Heritage Tourism: Authenticity and Commodification. Annals of Tourism Research 28(3), 565-580.

Hewison, R. (1987) The Heritage Industry: Britain in a Climate of Decline, Methuen, London.

Holcomb, B. (1998) Gender and heritage interpretation, in Contemporary Issues 
in Heritage and Environmental Interpretation (edited by D. Uzzell and R. Ballantyne), The Stationery Office, London, pp. 37-55.

Hollinshead, K. (1997) Heritage tourism under post-modernity: truth and the past, in The Tourist Experience: A New Introduction (edited by C. Ryan), Cassell, London, pp. 170-193.

Kershaw, B. (1999) The Radical in Performance: Between Brecht and Baudrillard, Routledge, London.

Kershaw, B. (1996) The politics of performance in a postmodern age, in Campbell op. cit., pp. 133-152.

Milling, J. and Ley, G. (2000) Modern Theories of Performance, Palgrave, Houndmills, Basingstoke, Hants.

Mills, S.F. (1997) The American Landscape, Keele University Press, Edinburgh.

Mills, S.F. and Tivers, J. (2000) Living history: gendered space in the modern museum, paper presented to the Annual Conference of the Royal Geog-raphical Society/Institute of British Geographers, University of Sussex.

Parker, A. and Sedgwick, E.K. (1995) Introduction: Performativity and Performance, in Performativity and Performance, (edited by A. Parker and E.K. Sedgwick), Routledge, London, pp. 1-18.

Roach, J. (1995) Culture and Performance in the Circum-Atlantic World, in Parker and Sedgwick op. cit., pp. 45-63.

Robertshaw, A. (1997) “A dry shell of the past”: Living history and the interpretation of historic houses. Interpretation 2(3), 1-7.

Rojek, C. (1994) Ways of Escape: Modern Transformations in Leisure and 
Travel, Rowman \& Littlefield, Lanham, Maryland.

Rumble, P. (1989) Interpreting the Built and Historic Environment, in Uzzell op. cit., pp. 24-32.

Schouten, F.F.J. (1995) Heritage as Historical Reality, in Heritage, Tourism and Society (edited by D.T. Herbert), Mansell, London, pp. 21-31.

Taylor, J.P. (2001) Authenticity and Sincerity in Tourism. Annals of Tourism Research 28(1), 7-26.

Turner, V. (1982) From Ritual to Theatre: The Human Seriousness of Play, PAJ Publications, New York.

Uzzell, D. (1989) The Hot Interpretation of War and Conflict, in Uzzell op. cit., pp. 33-47.

Williams, R. (2000) Drama in a Dramatized Society, in Goodman and De Gay op. cit., pp. 55-59. 